\title{
Thysanoptera of the Galápagos Islands ${ }^{1}$
}

\author{
Mark S. Hoddle ${ }^{2,3,5}$ and Laurence A. Mound ${ }^{4}$
}

\begin{abstract}
Thysanoptera from the Galápagos Islands were inventoried from 627 slide-mounted specimens that were made with material that had been stored at the Reference Collection of Terrestrial Invertebrates at the Charles Darwin Research Station, Galápagos, Ecuador. Museum material was complemented by field collections conducted over the period October-November 2009. This inventory was augmented from records in the published literature. Identification of museum and field-collected material added an additional 27 species to the already known fauna, an increase of 54\%. A total of 77 species of thrips from 42 genera in four families is now known from 17 different islands in the Galápagos. At least nine species are serious pests, of which four, Frankliniella occidentalis, Gynaikotbrips uzeli, Thrips palmi, and Thrips tabaci, are reported from the Galápagos Islands in the primary scientific literature for the first time.
\end{abstract}

Thrips (order Thysanoptera) are very small insects that have evolved various dietary habits among which phytophagy, predation, and the consumption of fungal spores are common. Due to their very small size, thrips are among the stealthiest of insect invaders (Morse and Hoddle 2006). Species have been moved globally due to the trade in living plants, or in dry plant material used for packaging, or in dehydrated plant foodstuffs for livestock (Mound and Walker 1987, Morse and Hoddle 2006). Previous surveys for thrips on South Pacific islands have indicated that the majority of species collected are exotic and likely accidentally introduced by humans.

\footnotetext{
${ }^{1}$ Manuscript accepted 4 February 2011.

2 Department of Entomology, University of California, Riverside, California 92521.

${ }^{3}$ Center for Invasive Species Research, University of California, Riverside, California 92521.

${ }^{4}$ Honorary Research Fellow, CSIRO Ecosystems Sciences, G.P.O. Box 1700, Canberra, Australian Capital Territory 2601, Australia. edu).

${ }^{5}$ Corresponding author (e-mail: mark.hoddle@ucr.
}

Pacific Science (2011), vol. 65, no. 4:507-513

doi: $10.2984 / 65.4 .507$

(C) 2011 by University of Hawai'i Press

All rights reserved
Surveys completed for islands or island groups in the South Pacific such as French Polynesia (Hoddle et al. 2008a); Kiribati, Vanuatu, and Fiji (Mound and Walker 1987); Lord Howe Island (Mound 1998); and New Caledonia (Bournier and Mound 2000) suggest that few thrips species are endemic. The majority of species inventoried have originated from Europe, Australia, and the Old and New World tropics. In addition, it has been estimated that $\sim 45 \%$ of terebrantian thrips in New Zealand are of exotic origin (Mound and Walker 1982, Mound 2006), and in California, an area of the United States with a rich endemic thrips fauna that borders the Pacific Ocean, 20\% of known species originated elsewhere (Hoddle et al. 2004).

The Galápagos Islands comprise 18 major islands that straddle the equator in the $\mathrm{Pa}$ cific Ocean $973 \mathrm{~km}$ west of Ecuador (Anon. 2010). Accidental introductions of insects into the Galápagos are increasing exponentially because of human activities (Causton et al. 2006). Every month at least 80 commercial flights enter the Galápagos and $~ 100,000$ tourists visit the islands each year, and the number of human inhabitants is increasing by $5.8 \%$ per annum (Causton et al. 2006). A major obstacle to managing invasive species introductions into the Galápagos is the lack of baseline data for exotic insect species, 
especially in urban and agricultural zones. This is a serious problem for quarantine managers in charge of rapid containment, elimination, or early warning monitoring programs because detection of a previously undocumented insect species, for example, a thrips, may be a new introduction or possibly the first identification of an unrecognized insect that is already well established throughout the archipelago (Causton et al. 2006).

Two previous publications have documented the thrips fauna in the Galápagos. The first was by Bailey (1967), who identified eight species in six genera encompassing three families. That list was updated to 50 species representing 31 genera in four families by Peck (2001), whose thrips identifications were made by Sueo Nakahara (Systematic Entomology Laboratory, U.S. Department of Agriculture, Beltsville, Maryland). The project reported upon here builds upon Peck's (2001) inventory to better document the Thysanoptera fauna of these iconic islands. The results from limited field collections and examination of previously unstudied museum specimens are presented here and strengthen the baseline database for these insects in the Galápagos.

\section{MATERIALS AND METHODS}

\section{Collection of Specimens}

The majority of specimens used in this study were provided by the Reference Collection of Terrestrial Invertebrates at the Charles Darwin Research Station (IC CDRS), in Puerto Ayora, Santa Cruz, in the Galápagos Islands, Ecuador. All museum material used for this study was preserved in $70 \%$ ethanol and had been collected over the period 1983-2003. Various indiscriminant trapping methods including malaise traps, flight interception traps, yellow pan traps, suction traps, pitfall traps, and sweep netting had been used in projects surveying the insect fauna of the Galápagos. From this material thrips had been sorted and preserved in 70\% ethanol with collecting labels. However, these unselective collection techniques provide little information about the association of thrips with particular host plants, especially indigenous and endemic species, which could have been very useful in deciding the endemicity of some collected species. In addition, much of the material had deteriorated from prolonged storage periods in ethanol in full light at room temperature. Color loss and body deformation were very obvious upon preparing material for mounting into balsam on glass slides.

An attempt was made by M.S.H. in October-November 2009 to rectify these two problems (i.e., lack of plant association data and poor-quality aged specimens) by beat sampling native, exotic, and crop plants over a white plastic tray. Dislodged thrips were collected with a fine paint brush and placed in labeled vials of $95 \%$ ethanol for identification. If the identity of sampled plants was unknown, digital photos or labeled samples were taken for later identification and cross-referenced to collection vials. Surveys were conducted in urban, agricultural, and undisturbed natural areas and Global Positioning System (GPS) coordinates of all sampling locations that yielded material were recorded. Thrips were collected and exported from the Galápagos under a permit issued by the Parque Nacional Galápagos, authorization number 089/2009 PNG. Specimens collected in 2009 were prepared as described here and mounted in balsam within 3 months of collection. This slidemounted material is of much higher quality than the $70 \%$ ethanol-preserved museum specimens.

\section{Preparation of Material for Identification}

All collected material was macerated in 5\% $\mathrm{NaOH}$ and subjected to dehydration in an ethanol series and clove oil before being mounted onto glass slides in Canada balsam (see Mound and Marullo [1996], Moritz et al. [2001], and Hoddle et al. [2008b] for details on slide mounting thrips).

\section{Identification and Museum Deposition of Slide-Mounted Specimens}

Slide-mounted specimens were identified using published keys (e.g., Mound 1999, Moritz et al. 2001, Hoddle et al. $2008 b$ [and the refer- 
ences contained within]). Species identity was confirmed by comparison with already identified slide-mounted material held at the Australian National Insect Collection and the University of California, Riverside. Identified material has been deposited in the Entomology Museum at the University of California, Riverside; the Australian National Insect Collection, Canberra, Australia; and IC CDRS.

\section{RESULTS AND DISCUSSION}

Over the course of this study, 672 thrips from the Galápagos Islands were slide mounted and identified. The total number of species identified from museum and field-collected material was 43 species in 29 genera encompassing four families (Aeolothripidae, Merothripidae, Thripidae, and Phaelothripidae). Of these 43 species, 27 (63\%) were new records for the Galápagos, and when combined with species lists from Bailey (1967) and Peck (2001) the total number of known thrips species for the Galápagos is now 77, an increase of $54 \%$ (Table 1).

We estimate that $\sim 10$ species $(\sim 13 \%)$ of those listed here are adventives having originated either from Europe (one species, Thrips tabaci) or from the Old World tropics (nine species) (Table 1). The potential number of indigenous thrips, species likely endemic to the New World and found on the Galápagos, is high, $\sim 42$ species ( $55 \%)$. However, the number of thrips species endemic to these islands is likely low, possibly $<20 \%$ of identified species. This estimate is based on genera being endemic to the New World, but species identifications were not possible because keys are lacking and the genera of interest and their species are not well studied. Consequently, this tentative estimate may be overestimating the number of thrips species endemic to the Galápagos.

Four major obstacles are apparent when trying to determine if thrips are indigenous or endemic to the Galápagos and for cataloguing species diversity in general: (1) poor knowledge of the thrips fauna of South America, especially Ecuador and other countries that border the Pacific Ocean. Improved knowledge of the thrips fauna in this area would provide a database for comparing the closest continental species to those collected on the Galápagos, which would help resolve questions pertaining to whether or not species are native or endemic; (2) systematic surveys with collection techniques, such as beat tray sampling, specifically for thrips have not been undertaken. At a minimum it is recommended that this should be conducted for the four main islands of the Galápagos (Santa Cruz, Isabela, San Cristóbal, and Floreana) that have the highest and longest levels of human occupation, trade, plant diversity, and agriculture, features that facilitate incursion by thrips. Information from this type of focused sampling would greatly improve our understanding of host plant use and habitat preferences and would likely uncover additional undocumented species and possibly provide information on the impacts of pest species in anthropogenic and natural environments. For example, beat tray sampling of plants resulted in the collection of 27 species of thrips (Table 1) from 25 different plant species in 14 families (Table 2). These are the first plant association or substrate data for thrips in the Galápagos. However, the use of these plants for feeding and reproduction has not been confirmed, so plants from which thrips were collected cannot be assumed to be hosts; (3) use of indiscriminant trapping methods, like malaise traps, provides little data on host plant use and specificity, densities of thrips on plants or other food substrates, or associations with other insects. These types of data, when available, can be extremely instructive. For example, beat sampling revealed that Androthrips ramachandrai, a predator, was always associated with Gynaikothrips uzeli inside galled Ficus sp. leaves in urban areas in Puerto Ayora, Santa Cruz. This result suggests that this predator is possibly host specific and probably invaded the Galápagos with G. uzeli. Further, nonselective collection techniques may inadvertently favor the capture of certain thrips groups because of their preferred mode of movement (e.g., winged species being caught in flight interception traps); (4) because major efforts have been directed at sampling insects in natural areas of the Galápagos, urban and agricultural zones have been largely 
TABLE 1

Thrips Species Collected from Different Islands in the Galápagos and Grouped by Feeding Guild

\begin{tabular}{|c|c|}
\hline Taxon & Islands from Which Thrips Were Collected \\
\hline \multicolumn{2}{|l|}{ Flower-feeding thrips } \\
\hline $\mathrm{A}, \mathrm{D}, \mathrm{F}, \mathrm{G}, \mathrm{R}, \mathrm{S}, \mathrm{U}, \beta$ Frankliniella bruneri $\mathrm{Watson}{ }^{0}$ & Baltra, Floreana, Isabela, Santa Cruz \\
\hline${ }^{\mathrm{P}, \mathrm{V}, \beta}$ Frankliniella brunnea Priesner $^{0}$ & Floreana, Santa Cruz \\
\hline${ }^{\mathrm{U}, \beta}$ Frankliniella citripes $\mathrm{Hood}^{0}$ & Santa Cruz \\
\hline $\mathrm{F}, \mathrm{S}, \mathrm{X}, \beta$ Frankliniella insularis (Franklin) ${ }^{0}$ & Floreana, San Cristóbal, Santa Cruz \\
\hline${ }^{\mathrm{D},+, \beta}$ Frankliniella occidentalis (Pergande $)^{0}$ & Floreana, Santa Cruz \\
\hline${ }^{\beta}$ Frankliniella rodeos Moulton ${ }^{1,3}$ & Duncan Island ${ }^{1}$, Pinzón $^{3}$, Santa Cruz ${ }^{1,3}$ \\
\hline${ }^{\dagger, \beta}$ Frankliniella schultzei Trybom ${ }^{0,3}$ & Floreana $^{0}$, Isabela $^{0}$, Santa Cruz $^{3}$, Wolf ${ }^{0}$ \\
\hline${ }^{\beta}$ Frankliniella sp. (yellow) ${ }^{3,4}$ & $\begin{array}{l}\text { Española }{ }^{3}, \text { Fernandina }^{3}, \text { Floreana }^{3} \text {, Isabela } \\
\text { Santa } \text { Cruz }^{3,4}, \text { Pintiago }^{3}, \text { Rábida }^{3} \text {, }\end{array}$ \\
\hline${ }^{\beta}$ Frankliniella sp. (brown $)^{3}$ & Santa Cruz, Santiago \\
\hline${ }^{\mathrm{M}, Z, \Delta}$ Haplotbrips gowdeyi Franklin ${ }^{0,2,3,4}$ & $\begin{array}{l}\text { Duncan }{ }^{2}, \text { Fernandina }{ }^{3}, \text { Floreana }^{4}, \text { Genovesa }^{3}, \text { Isabela }^{4}, \text { Pinzón }^{3} \text {, } \\
\text { Rábida }^{3}, \text { San Cristóbal }{ }^{0}, \text { Santa } \text { Cruz }^{3} \text {, Santiago }\end{array}$ \\
\hline C,F,R,S,U,,,$\Delta$ Thrips palmi Karny $^{0}$ & Santa Cruz \\
\hline Thrips sp. ${ }^{3}$ pom & Isabela $^{3}$ \\
\hline${ }^{\mathrm{B}, t, \alpha}{ }^{T}$ Thrips tabaci Lindeman ${ }^{0}$ & Santa Cruz \\
\hline \multicolumn{2}{|l|}{ Leaf-feeding thrips } \\
\hline${ }^{\beta}$ Baileyothrips limbatus (Hood) ${ }^{3}$ & Marchena ${ }^{3}$, Pinta ${ }^{3}$ \\
\hline${ }^{\dagger, \Delta}$ Chaetanaphothrips orchidii (Moulton) ${ }^{3}$ & Isabela ${ }^{3}$ \\
\hline${ }^{\mathrm{N},+, \beta}$ Caliothrips phaseoli (Hood) ${ }^{3,4}$ & Fernandina ${ }^{3}$, Floreana $^{3}$, Isabela $^{4}$, Pinta $^{3}$, Santa Cruz $^{4}$ \\
\hline${ }_{\mathrm{I}, \mathrm{P}, \Delta}$ Elixothrips brevisetis (Bagnall) ${ }^{0}$ & Santa Cruz \\
\hline${ }_{\mathrm{L}, \mathrm{t}, \Delta}$ Gynaikothrips uzeli Hinds $^{0}$ & San Cristóbal, Santa Cruz \\
\hline Haplothrips sp. ${ }^{1}$ & Santa Cruz \\
\hline $\mathrm{H}, \mathrm{Q}, \mathrm{\dagger}, \beta$ Heliothrips haemorrhoidalis Bouché $\mathrm{e}^{0,3,4}$ & $\begin{array}{l}\text { Floreana } a^{0} \text { Isabela }^{3}, \text { Pinzón }^{3}, \text { San Cristóbal } \\
\text { Santiago }\end{array}$ \\
\hline${ }^{\mathrm{Z}}$ Liothrips sp. ${ }^{4}$ & San Cristóbal \\
\hline 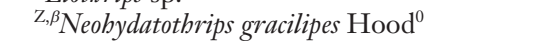 & Floreana, Isabela, San Cristóbal \\
\hline${ }^{\beta}$ Neobydatothrips portoricencis Morgan ${ }^{0}$ & Isabela $^{0}$ \\
\hline${ }^{\beta}$ Neobydatothrips williamsi Hood ${ }^{3,4}$ & Floreana $^{4}$, Isabela ${ }^{4}$, Santa $\mathrm{Cruz}^{3}$ \\
\hline Neobydatotbrips sp. ${ }^{3}$ & Floreana, Isabela, Marchena, Pinta, Santa Cruz \\
\hline${ }^{\beta}$ Plesiotbrips brunneus Hood $^{3}$ & Isabela, Santa Cruz, Santiago \\
\hline${ }^{\beta}$ Plesiothrips perplexus Beach $^{0,3,4}$ & Floreana $^{0}$, Isabella ${ }^{4}$, Santa Cruz $^{3}$, Santiago $^{3}$ \\
\hline Plesiotbrips sp. ${ }^{0}$ & Floreana \\
\hline${ }^{\mathrm{W}, \Delta}$ Rhamphothrips sp. ${ }^{0}$ & Santa Cruz \\
\hline${ }^{\beta}$ Scirtothrips panamensis Hood $^{3}$ & Fernandina, Marchena, Santa Cruz, Santiago \\
\hline Scirtothrips sp. ${ }^{0,3}$ & Isabela \\
\hline $\mathrm{G}, \mathrm{H}, \mathrm{J}, \mathrm{O},+, \beta$ Selenothrips rubrocinctus Giard $^{0,4}$ & Floreana $^{4}$, Isabela ${ }^{4}$, San Cristóbal ${ }^{0}$, Santa $\mathrm{Cruz}^{4}$, Santiago $^{4}$ \\
\hline \multicolumn{2}{|l|}{ Grass-feeding thrips } \\
\hline${ }^{\beta}$ Adraneothrips tibialis (Hood) ${ }^{3}$ & Santa Cruz \\
\hline${ }^{\beta}$ Adraneothrips sp. ${ }^{3}$ & Rábida, Santa Cruz \\
\hline${ }^{\mathrm{M}, \beta}$ Arorathrips mexicanus (Crawford) ${ }^{0}$ & San Cristóbal \\
\hline${ }^{\Delta}$ Bamboosiella cingulata (Hood) $)^{0,3,4}$ & Floreana $^{4}$, Isabella ${ }^{0}$, San Cristóbal ${ }^{0}$, Santa Cruz $^{3}$ \\
\hline${ }_{\mathrm{M}, \beta}^{\beta}$ Bregmatothrips venustus Hood $^{0}$ & San Cristóbal \\
\hline${ }^{\beta}$ Caliothrips insularis (Hood) ${ }^{3}$ & Santa Cruz ${ }^{3}$ \\
\hline${ }^{\beta}$ Caliothrips punctipennis (Hood) ${ }^{4}$ & Isabela $^{4}$ \\
\hline \multicolumn{2}{|l|}{ Moss-feeding thrips } \\
\hline${ }^{\beta}$ Williamsiella morgani $(\mathrm{Hood})^{3}$ & Isabela, Pinzón \\
\hline \multicolumn{2}{|l|}{ Fungus-feeding thrips } \\
\hline${ }^{\beta}$ Allothrips mexicanus Stannard ${ }^{3}$ & Santa Cruz, Santa Fé \\
\hline Allotbrips sp. ${ }^{0}$ & Marchena \\
\hline${ }^{\beta}$ Apterygotbrips sp. ${ }^{0}$ & Isabela, Santiago \\
\hline${ }^{\beta}$ Carathrips rufescens (Hood) ${ }^{3}$ & Fernandina, Floreana, Isabela, Marchena, Santa Cruz \\
\hline${ }^{\beta}$ Gastrothrips harti (Hood) ${ }^{3}$ & Española, Santa Cruz \\
\hline Gastrothrips sp. nr. callipus ${ }^{3}$ & Española, Pinta, Santa Cruz \\
\hline Gastrothrips sp. ${ }^{3}$ & Santa Cruz \\
\hline Hoplandrothrips sp. ${ }^{0,3}$ & Floreana $^{0}$, Isabela $^{3}$, Pinta $^{3}$, Santa $\mathrm{Cruz}^{3}$ \\
\hline
\end{tabular}


TABLE 1 (continued)

\begin{tabular}{|c|c|}
\hline Taxon & Islands from Which Thrips Were Collected \\
\hline${ }^{\beta}$ Hoplandrothrips symmetricus $\mathrm{Hood}^{0}$ & Isabela \\
\hline${ }^{\beta}$ Hoplothrips angusticeps (Hood) ${ }^{3}$ & $\begin{array}{l}\text { Fernandina, Floreana, Isabela, San Cristóbal, Santa Cruz, } \\
\text { Santiago }\end{array}$ \\
\hline${ }^{\beta}$ Macrophthalmothrips belenae Hood ${ }^{3}$ & Isabela, San Cristóbal, Santa Cruz \\
\hline${ }^{\beta}$ Merothrips floridensis Watson ${ }^{0}$ & Isabela \\
\hline${ }^{\beta}$ Merotbrips morgani Hood $^{3}$ & Isabela $^{3}$, Santa $\mathrm{Cruz}^{3}$ \\
\hline $\mathrm{G}, \mathrm{K}, \mathrm{Z}, \Delta$ Nesothrips lativentris (Karny) ${ }^{3,4}$ & $\begin{array}{l}\text { Fernandina }{ }^{3}, \text { Floreana }^{4} \text {, Isabela }{ }^{4}, \text { Pinta }^{3} \text {, San Cristóbal }{ }^{4} \text {, Santa } \\
\text { Cruz }^{4}, \text { Santiago }^{3}\end{array}$ \\
\hline${ }^{\beta}$ Pygmaeothrips angusticeps Hood ${ }^{0,2}$ & Floreana $^{0}$, San Cristóbal ${ }^{0}$, Santa Cruz $^{2}$ \\
\hline${ }^{\beta}$ Scopaeothrips unicolor Hood $^{3}$ & Isabela \\
\hline${ }_{\mathrm{K}, \beta}$ Stephanothrips occidentalis Hood \& Williams ${ }^{0}$ & San Cristóbal \\
\hline${ }^{\beta}$ Strepterothrips floridanus (Hood) ${ }^{2,3,4}$ & $\begin{array}{l}\text { Española } \\
\text { Cruz }^{2}\end{array}$ \\
\hline Strepterothrips sp. ${ }^{3}$ & Española, Isabela, Marchena, Santa Cruz, Santiago \\
\hline${ }^{\beta}$ Trachythrips astutus $\operatorname{Cott}^{1}$ & South Plaza \\
\hline Trachythrips sp. nr. watsoni ${ }^{3}$ & Isabela \\
\hline Trichinotbrips sp. ${ }^{3}$ & Pinta, Santa Cruz \\
\hline${ }^{\beta}$ Zaliothrips sp. $^{\sigma}$ & San Cristobal \\
\hline $\mathrm{P}, \beta$ Zeugmatothrips hoodi Priesner $^{0}$ & Santa Cruz \\
\hline \multicolumn{2}{|l|}{ Predatory thrips } \\
\hline${ }^{\mathrm{L}, \Delta}$ Androthrips ramachandrai Karny $^{0}$ & Santa Cruz \\
\hline${ }^{\mathrm{T}, \mathrm{Y}, \beta}$ Franklinothrips vespiformis Crawford ${ }^{3,4}$ & Isabela $^{4}$, Pinzón ${ }^{3}$, Santa $\mathrm{Cruz}^{4}$ \\
\hline${ }^{\beta}$ Karnyothrips caliginosus Hood $^{3,4}$ & Isabela $^{4}$, Santiago $^{3}$ \\
\hline${ }^{\mathrm{H}, \beta}$ Karnyothrips flavipes Jones ${ }^{0}$ & Isabela \\
\hline${ }_{\mathrm{D}, \mathrm{H}, \mathrm{K}, \mathrm{Z}, \beta}$ Karnyotbrips melaleucus (Bagnall) ${ }^{3,4}$ & $\begin{array}{l}\text { Fernandina }{ }^{3} \text {, Floreana }{ }^{4} \text {, Genovesa }{ }^{3} \text {, Isabela }{ }^{4}, \text { Marchena }^{3} \text {, } \text { Pinta }^{3} \text {, } \\
\text { San Cristóbal }{ }^{4} \text {, Santa Cruz }\end{array}$ \\
\hline${ }^{\beta}$ Karnyothrips sonorensis Stannard ${ }^{1}$ & Santa Cruz \\
\hline Karnyotbrips sp. ${ }^{0}$ & Floreana \\
\hline Karnyothrips sp. nr. longiceps ${ }^{3}$ & Santa Cruz, Santiago \\
\hline $\mathrm{D}, \mathrm{E}, \mathrm{Z}, \tilde{\beta}$ Leptothrips sp. ${ }^{0}$ & Española, San Cristóbal, Santa Cruz \\
\hline${ }^{\beta}$ Leptothrips sp. nr. yaqui ${ }^{3}$ & Española ${ }^{3}$, Fernandina $^{3}$, Pinta $^{3}$, Santa $\mathrm{Cruz}^{3}$ \\
\hline Scolothrips pallidus (Beach) ${ }^{1}$ & Santa Cruz \\
\hline Scolothrips sexmaculatus (Pergande) ${ }^{3}$ & Pinzón \\
\hline Scolothrips sp. ${ }^{0,3}$ & Floreana $^{0,3}$, Isabela ${ }^{3}$, Santa Cruz $^{3}$ \\
\hline
\end{tabular}

Note: A,B,C, etc., Superscript letters reference host substrates from which thrips were collected, as shown in Table 2; ${ }^{\dagger}$, recognized pest species of thrips attacking agricultural crops and urban landscape plants; ${ }^{\alpha,}$ species of European origin; ${ }^{\Delta,}$ species that originated from the Old World tropics; ${ }^{\beta,}$, species of New World origin; ${ }^{?}$, area of origin uncertain for these species; ${ }^{0,}$ first records of species identified by the authors from museum or field-collected specimens; ${ }^{1}$ species listed by Bailey (1967) (we did not examine these specimens) but not collected in this study; ${ }^{2,}$ species listed by Bailey (1967) (we did not examine the Bailey material) and also collected in this study; ${ }^{3,}$ species listed by Peck (2001) (we did not examine these specimens) but not collected in this study; ${ }^{4}$, species listed by Peck (2001) (we did not examine the Peck material) and also collected in this study.

overlooked. Consequently, sampling bias of this nature most likely resulted in the failure to detect important agricultural pest species, in particular Frankliniella occidentalis, Thrips palmi, and Thrips tabaci, all of which were collected by beat tray sampling in 2009 .

In conclusion, our understanding of the Thysanoptera of the Galápagos Islands is rudimentary and consists primarily of species that have been collected as part of larger sam- pling and inventorying efforts. We suspect that for the Galápagos, as for other Pacific Ocean island groups, the number of endemic species is likely to be low ( $<20 \%$ ?). However, because very little information is available on host plant utilization by thrips, especially those inhabiting natural areas, this assumption could be incorrect. This is a hypothesis waiting to be tested, and targeted collecting efforts that focus on native host plants could 
TABLE 2

Host Substrate Associations for Thrips Collected by Beat Tray Sampling

\begin{tabular}{|c|c|c|}
\hline Letter $^{a}$ & Host Plant & Family \\
\hline $\mathrm{A}$ & Acacia sp. & Mimosaceae \\
\hline B & Allium cepa & Alliaceae \\
\hline $\mathrm{C}$ & Allium wakegi & Alliaceae \\
\hline $\mathrm{D}$ & $\begin{array}{l}\text { Alternanthera } \\
\text { echinocephala }\end{array}$ & Amaranthaceae \\
\hline $\mathrm{E}$ & Alternantbera filifolia & Amaranthaceae \\
\hline $\mathrm{F}$ & Brassica sp. & Brassicaceae \\
\hline G & Capsicum sp. & Solanaceae \\
\hline $\mathrm{H}$ & Cassia sp. & Fabaceae \\
\hline I & Chiococa alba & Rubiaceae \\
\hline $\mathrm{J}$ & Conocarpus erectus & Combretaceae \\
\hline $\mathrm{K}$ & Dead grass & Poaceae \\
\hline $\mathrm{L}$ & Ficus sp. & Moraceae \\
\hline M & Grasses & Poaceae \\
\hline $\mathrm{N}$ & $\begin{array}{l}\text { Heliotropium } \\
\text { curvassavicum }\end{array}$ & Boraginaceae \\
\hline $\mathrm{O}$ & Laguncularia racemosa & Combretaceae \\
\hline $\mathrm{P}$ & Lantana camara & Verbenaceae \\
\hline Q & Miconia robinsoniana & Melastomataceae \\
\hline $\mathrm{R}$ & Phaseolus vulgaris & Fabaceae \\
\hline $\mathrm{S}$ & Pisum sativum & Fabaceae \\
\hline $\mathrm{T}$ & Scutia spicata & Rhamnaceae \\
\hline $\mathrm{U}$ & Solanum lycopersicum & Solanaceae \\
\hline $\mathrm{V}$ & Tournefortia pubescens & Boraginaceae \\
\hline W & Tournefortia rufo-sericea & Boraginaceae \\
\hline$X$ & Unidentified legume & \\
\hline $\mathrm{Y}$ & Unidentified shrub & \\
\hline$Z$ & Weeds & \\
\hline
\end{tabular}

${ }^{a}$ Letters cross-reference to thrips collection data presented in Table 1.

be very helpful to answer questions pertaining to the level of endemicity for Thysanoptera in the Galápagos.

\section{ACKNOWLEDGMENTS}

We thank Henri W. Herrera, manager of the IC CDRS in Puerto Ayora, Santa Cruz Island, Galápagos, for access to preserved thrips material that was used in the preparation of this checklist. Christina Hoddle, Department of Entomology, University of California, Riverside, assisted with field collections of thrips in the Galápagos. Ruth Amrich, Department of Entomology, University of California, Riverside, helped prepare, slide mount, and label thrips that were examined for this project.

\section{Literature Cited}

Anon. 2010. Galápagos Islands. http://en .wikipedia.org/wiki/Gal\% C3\%A1pagos_ Islands (accessed 23 November 2010).

Bailey, S. F. 1967. A collection of Thysanoptera from the Galapagos Islands. Pan-Pac. Entomol. 43:203-210.

Bournier, J. P., and L. A. Mound. 2000. Inventaire commenté des Thysanoptères de Nouvelle-Calédonie. Bull. Soc. Entomol. Fr. 105:231-240.

Causton, C. E., S. B. Peck, B. J. Sinclair, L. Roque-Albelo, C. J. Hodgson, and B. Landry. 2006. Alien insects: Threats and implications for conservation of Galápagos Islands. Ann. Entomol. Soc. Am. 99:121143.

Hoddle, M. S., C. D. Hoddle, and L. A. Mound. 2008a. Inventory of Thysanoptera collected from French Polynesia. Pac. Sci. 62:509-515.

Hoddle, M. S., L. A. Mound, and S. Nakahara. 2004. Thysanoptera recorded from California, U.S.A.: A checklist. Fla. Entomol. 87:317-323.

Hoddle, M. S., L. A. Mound, and D. Paris. 2008b. Thrips of California. CBIT, Brisbane. http://www.lucidcentral.org/keys/ v3/thrips_of_california.html (accessed 26 January 2011). CD-ROM.

Moritz, G., D. Morris, and L. Mound. 2001. ThripsID, Pest thrips of the world. ACIAR. Interactive CD-ROM.

Morse, J. G., and M. S. Hoddle. 2006. Invasion biology of thrips. Annu. Rev. Entomol. 51:67-89.

Mound, L. A. 1998. Thysanoptera from Lord Howe Island. Aust. Entomol. 25:113-120.

- 1999. Saltatorial leaf-feeding Thysanoptera (Thripidae: Dendrothripinae) from Australia and New Caledonia, with newly recorded pests of ferns, figs and mulberries. Aust. J. Entomol. 38:257-273.

- 2006. Vicariance or dispersal: TransTasman faunal relationships among Thysanoptera (Insecta), with a second species of Lomatothrips from Podocarpus. Pap. Proc. R. Soc. Tasman. 140:11-15.

Mound, L. A., and R. Marullo. 1996. The thrips of Central and South America: 
An introduction (Insecta: Thysanoptera). Memoirs on Entomology, International. Vol. 6. Associated Publishers, Gainesville, Florida.

Mound, L. A., and A. K. Walker. 1982. Terebrantia (Insecta: Thysanoptera). Fauna N. Z. 1:1-113.
—. 1987. Thysanoptera as tropical tramps: New records from New Zealand and the Pacific. N. Z. Entomol. 9:70-85.

Peck, S. B. 2001. Smaller orders of insects of the Galapagos Islands, Ecuador: Evolution, ecology, and diversity. NRC Research Press, Ottawa, Ontario, Canada. 
